\title{
Book Review 'Mencegah, Merawat Dan Memulihkan Penagih Dadah: Beberapa Pendekatan Dan Amalan Dì Malaysia' (Malay Version)
}

\author{
Uqbah iqbal* \\ Faculty of Social Sciences and Humanities, UKM Bangi Selangor, Malaysia
}

Submission: August 23, 2017; Published: September 21, 2017

*Corresponding author: Uqbah iqbal, Faculty of Social Sciences and Humanities, UKM, Bangi Selangor, Malaysia, Email: uqbah@siswa.ukm.edu.my

\section{Introduction}

Written by Mahmood Nazar Mohamed, efforts to treat and rehabilitate drug addicts should be continued by seeking more effective treatment procedures and methods. With reduced dependency on drugs, then intergratically, other ancillary problems have also been resolved such as criminal behavior, antisocial and other miscellaneous activities. In this regard, it is the responsibility of all parties involved, whether government agencies, NGOs or researchers to identify and implement more effective treatment and remedial methods. The Malaysian government has taken an active and decisive step in 2003 to combat drug abuse completely. Therefore, in 2003 it was gazetted as the Year of Fighting Drug Outpatient. All parties have been called upon to mobilize to achieve these objectives for mutual prosperity.

The 1 Malaysia Inabah Youth Cottage provides a drug addiction rehabilitation service to rehabilitate victims from drug addiction and guide them to the way of life that God is pleased with. The guidance given to them towards a balanced spiritual and physical life is expected to help reduce the burden of drugs and ultimately the drug addiction can be avoided and eliminated. Scientific research and observations on drug addiction problems show that one of the major causes of individuals involved with drug abuse is because they live a life that is incompatible with human nature. The life they go through is not balanced in terms of physical needs with spiritual needs. Nowadays, drug addicts today are those who have good, educated, skilled, well-being, comfortable living and unparalleled physical needs. But they are still looking for happiness, satisfaction and feeling unsatisfied and hard to feel grateful. So many are trapped in this quest.

There are three types or treatment modality and drug rehabilitation arising from the problem of drug addiction that extends widely in the 1960s, namely Residential Therapeutic Community (TC), Methadone Maintenance (MM) rehabilitation and Outpatient Rehabilitation in a drug-free environment. (Outpatient Drug Free - ODF). The TC was founded by a former alcoholic named Charles Dederich in 1958. During the year he established Synanon, a residential-built rehabilitation home which provided the opportunity for drug addicts to re-establish a productive society through group meetings and other forms of TC therapy. The TC program has now been received globally and it is managed by former drug addicts. The second is the Methadone Maintenance (MM) which was originally founded through the research work of Dr. Vincent Dole and Dr. Marie Nyswander in 1964.

The theory behind MM is to provide a relatively significant methadone dose $(80-120 \mathrm{mg} /$ day) to drug addicts whose result is the recipient of opiate signals located in the brain's organs will be prevented from producing addictive signals to obtain narcotic supply. The third type is Outpatient Drug Free which starts with the urgency and need to set up referral centers for addicts in their own community. The purpose of the outpatient center is to be used by drug addicts when dealing with difficult crisis situations solely. Filling centers like this is a counseling that is usually handled by former drug addicts and volunteers. 
(C) This work is licensed under Creative
Commons Attribution 4.0 Licens
DOI: $10.19080 /$ MABB.2017.02.555578

\section{Your next submission with Juniper Publishers} will reach you the below assets

- Quality Editorial service

- Swift Peer Review

- Reprints availability

- E-prints Service

- Manuscript Podcast for convenient understanding

- Global attainment for your research

- Manuscript accessibility in different formats

( Pdf, E-pub, Full Text, Audio)

- Unceasing customer service

Track the below URL for one-step submission https://juniperpublishers.com/online-submission.php 